\title{
Culture duration and conditions affect the oscillations of cytoplasmic calcium concentration induced by glucose in mouse pancreatic islets
}

\author{
P. Gilon, J. C. Jonas, J. C. Henquin \\ Unité d'Endocrinologie et Métabolisme, University of Louvain Faculty of Medicine, Brussels, Belgium
}

\begin{abstract}
Summary The pattern of the increase in cytoplasmic $\mathrm{Ca}_{\mathrm{i}}^{2+}$ that glucose produces in beta cells has been reported to be highly variable. Here, we evaluated the influence of the culture duration (1-4 days) and conditions $\left(5-10 \mathrm{mmol} / 1\right.$ glucose) on $\mathrm{Ca}_{i}{ }^{2+}$ in normal mouse islets stimulated by glucose. After 1 day of culture in $10 \mathrm{mmol} / \mathrm{l}$ glucose, a rise of the glucose concentration from 3 to $15 \mathrm{mmol} / \mathrm{l}$ induced a triphasic change of $\mathrm{Ca}_{i}{ }^{2+}$ in the islets. A small initial decrease was followed by a large peak increase and then by regular fast oscillations $(\sim 2.5 / \mathrm{min})$. When the culture was prolonged to 2,3 and 4 days, the initial decrease became inconsistent and the peak occurred earlier, whereas the oscillations decreased in frequency, increased in duration and eventually disappeared; on day 4 the $\mathrm{Ca}_{\mathrm{i}}{ }^{2+}$ rise was sustained. After culture in $5 \mathrm{mmol} / \mathrm{l}$ glucose, the pattern of $\mathrm{Ca}_{\mathrm{i}}{ }^{2+}$ changes induced by $15 \mathrm{mmol} / \mathrm{l}$ glucose was different. The initial
\end{abstract}

decrease was very pronounced, the first peak was delayed and clearly separated from the subsequent oscillations. These were of a mixed type (fast $\mathrm{Ca}^{2+}$ transients on top of slow ones) after 1 day, and of a slow type only after 4 days. These alterations in the $\mathrm{Ca}_{\mathrm{i}}{ }^{2+}$ oscillations triggered by glucose could not be ascribed to desynchronization of the signal between different regions of the islets. In conclusion, culturing normal mouse islets in 5 or $10 \mathrm{mmol} / 1$ glucose for 1 4 days, markedly alters the characteristics of the changes in $\mathrm{Ca}_{i}^{2+}$ produced by glucose. This pitfall must be borne in mind when studying stimulus-secretion coupling in beta cells from normal or diabetic animals, or from human islets. [Diabetologia (1994) 37: 1007-1014]

Key words Islets, culture, calcium, glucose, stimulussecretion coupling, beta cells.
The essential role of $\mathrm{Ca}^{2+}$ in the triggering of insulin secretion has been established beyond doubt [1-5]. Glucose and most other nutrient secretagogues promote $\mathrm{Ca}^{2+}$ influx in pancreatic beta cells. This influx occurs rhythmically during phases of electrical activity corresponding to slow waves of membrane depolarization and opening of voltage-dependent $\mathrm{Ca}^{2+}$ channels $[4,6,7]$.

Received: 21 February 1994

and in revised form: 25 May 1994

Corresponding author: Dr. J.C.Henquin, Unité d'Endocrinologie et Métabolisme, UCL 55.30, Avenue Hippocrate, 55, B-1200 Bruxelles, Belgium

Abbreviation: $\mathrm{Ca}_{\mathrm{i}}{ }^{2+}$, concentration of cytoplasmic calcium.
Since the development of fluorimetric methods to measure the concentration of free ions in intact cells, a number of studies have investigated the effects of various secretagogues on cytoplasmic $\mathrm{Ca}_{\mathrm{i}}{ }^{2+}$ in insulinsecreting cells. Suspensions of normal mouse [8] or rat [9] islet cells, of RINm5F cells [10] or of rat islets [11] were first used. Relatively straightforward conclusions could be drawn from the average changes that were recorded, in particular after the technique was improved by the use of dual-wavelength fluorometry $[12,13]$. With the further development of microtechniques and their application to the measurements of $\mathrm{Ca}_{\mathrm{i}}^{2+}$ in single islets or single beta cells, new questions have been raised which currently limit the significance of the observations. From studies using isolated rat or mouse beta cells cultured for 1 to 5 days [14-20], two conclusions have emerged. First, 
Culture G $10 \mathrm{mmol} / \mathrm{l}$
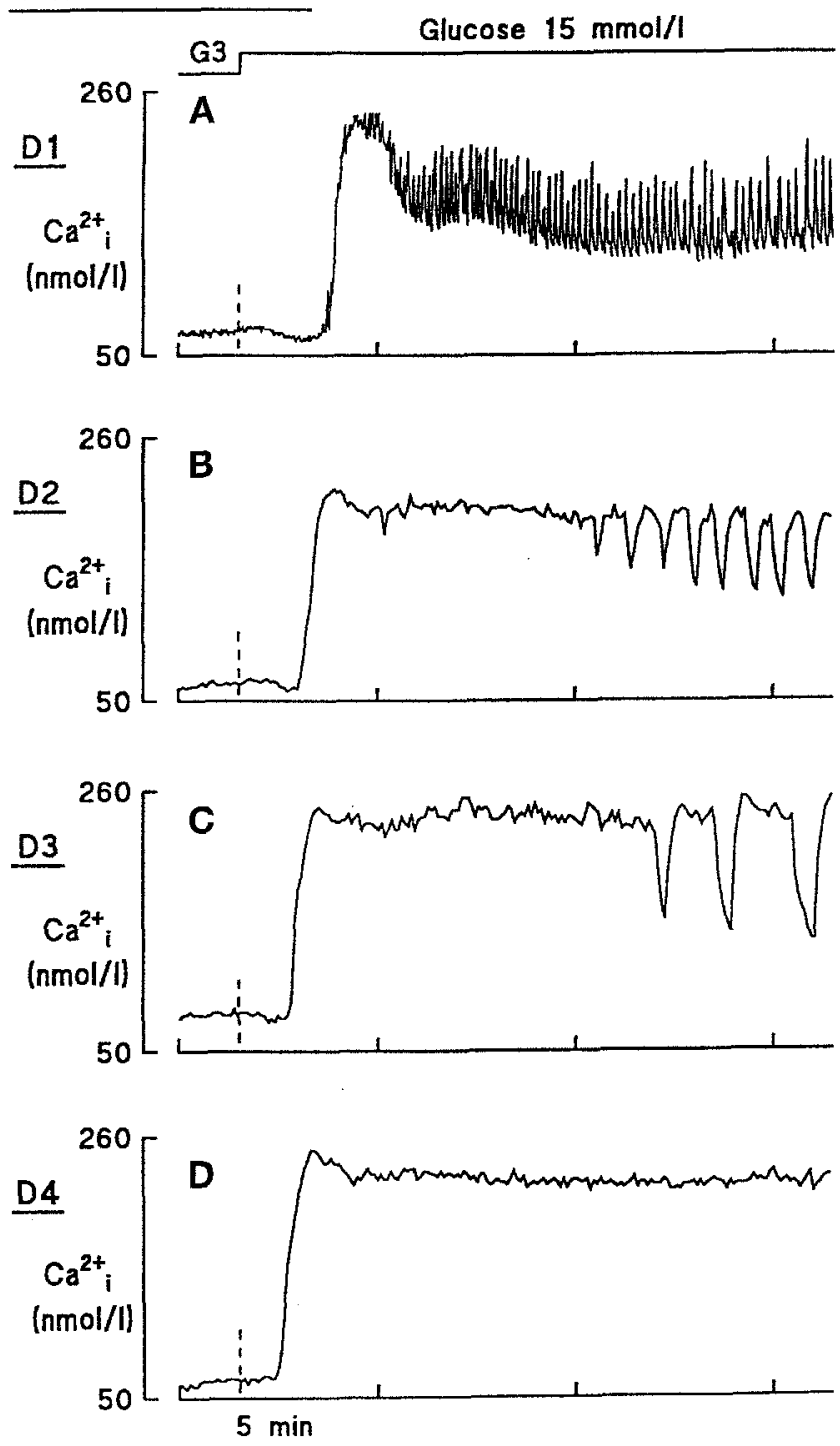

Fig. 1A-D. Influence of culture duration on the changes in $\mathrm{Ca}_{\mathrm{i}}{ }^{2+}$ occurring in mouse islets stimulated by an increase in glucose $(\mathrm{G})$ concentration from 3 to $15 \mathrm{mmol} / \mathrm{l}$. The islets were cultured in RPMI 1640 medium containing $10 \mathrm{mmol} / \mathrm{l}$ glucose for 1-4 days (D1-D4). They were then loaded with fura-2, transferred to the recording chamber, and perifused with a medium containing $3 \mathrm{mmol} / 1$ glucose for about $10 \mathrm{~min}$ before $\mathrm{Ca}_{\mathrm{i}}{ }^{2+}$ measurements started. These recordings are representative of results obtained in 18 (D1) or 12 (D2-D4) islets

there exists a marked variability of the individual $\mathrm{Ca}_{\mathrm{i}}{ }^{2+}$ responses to glucose. Second, $\mathrm{Ca}_{\mathrm{i}}{ }^{2+}$ oscillations are present in single beta cells stimulated by a constant concentration of glucose, but their frequency is highly variable and much lower $(0.05-0.5 / \mathrm{min})$ than that of the slow waves of membrane potential. These findings are in contrast with those obtained with mouse islets a few hours after isolation $[21,22]$ or after overnight culture $[23,24]$. In this model, the $\mathrm{Ca}_{\mathrm{i}}{ }^{2+}$ changes in response to glucose were found to be more homogeneous and to display oscillations with a similar frequency to those of the oscillations of membrane po- tential recorded in beta cells [22, 24]. However, in one study with rat islets cultured for 2-4 days, only slow oscillations of $\mathrm{Ca}_{\mathrm{i}}^{2+}$ were detected [25].

As a first step to understanding these discrepancies, we evaluated the influence of the culture duration (1-4 days) and of the glucose concentration during culture $(5$ or $10 \mathrm{mmol} / 1)$ on $\mathrm{Ca}_{\mathrm{i}}{ }^{2+}$ changes in normal mouse islets.

\section{Materials and methods}

Preparation and solutions. Islets were isolated aseptically after collagenase digestion of the pancreas of fed female NMRI mice $(25-30 \mathrm{~g})$. They were then cultured for $1-4$ days in RPMI 1640 medium (Flow Laboratories, ICN Biomedicals Ltd, Irvine, UK, or Sera Lab Ltd, Crawley Down, Sussex, UK) containing $10 \%$ heat-inactivated fetal calf serum, $100 \mathrm{IU} / \mathrm{ml}$ penicillin and $100 \mu \mathrm{g} / \mathrm{ml}$ streptomycin. The concentration of glucose was 5 or $10 \mathrm{mmol} / \mathrm{l}$. The culture medium was changed after 2 days.

The medium used for the isolation of islets and for all experiments was a bicarbonate-buffered solution containing: (in mniol/1) $120 \mathrm{NaCl}, 4.8 \mathrm{KCl}, 2.5 \mathrm{CaCl}_{2}, 1.2 \mathrm{MgCl}_{2}$ and $24 \mathrm{Na}$ $\mathrm{HCO}_{3}$. It was gassed with $\mathrm{O}_{2} / \mathrm{CO}_{2}(94 / 6)$ to maintain $\mathrm{pH} 7.4$, and was supplemented with $1 \mathrm{mg} / \mathrm{ml}$ bovine serum albumin (fraction V, Boehringer Mannheim, Mannheim, Germany).

Measurements of cytoplasmic $\mathrm{Ca}_{i}{ }^{2+}$. Cultured islets were loaded with fura- 2 during $40 \mathrm{~min}$ of incubation at $37^{\circ} \mathrm{C}$ in a bicarbonate-buffered solution containing $10 \mathrm{mmol} / \mathrm{l}$ glucose and $1 \mu \mathrm{mol} / 1$ fura-2-acetoxymethylester (Molecular Probes, Eugene, Or., USA; added from a $1 \mathrm{mmol} / \mathrm{l}$ stock solution in $\mathrm{Me}_{2} \mathrm{SO}$ ). In one series of control experiments, islets cultured in the presence of $5 \mathrm{mmol} / \mathrm{l}$ glucose were loaded with fura- 2 in a medium also containing $5 \mathrm{mmol} / 1$ glucose. These islets were not included in the quantification of $\mathrm{Ca}_{\mathrm{i}}{ }^{2+}$ changes. Islets of a similar, medium, size were used for all experiments. Large islets were not used because they survive less well in culture and inhomogeneously take up fura-2. Loaded islets were then transferred to a temperature-controlled perifusion chamber (Applied Imaging, Sunderland, UK) with a volume of approximately $1 \mathrm{ml}$ and a bottom made of a coverslip. The chamber was mounted on the stage of an inverted microscope. The islets were held in place by gentle suction with a glass micropipette. The chamber was perfused at a flow rate of $1.3 \mathrm{ml} / \mathrm{min}$. The dead space of the system $(2 \mathrm{~min})$ has been corrected for in figures and calculations. Perifusion solutions were kept at $38^{\circ} \mathrm{C}$ in a water bath and the temperature controller ensured a temperature of $37^{\circ} \mathrm{C}\left( \pm 0.3^{\circ} \mathrm{C}\right)$ in the chamber as monitored by a thermistor placed near the tissue.

The measurements of $\mathrm{Ca}_{\mathrm{i}}{ }^{2+}$ were performed with the system MagiCal (Applied Imaging) as recently described in detail [24]. The tissue was excited at 340 and $380 \mathrm{~nm}$. The fluorescence emitted at $510 \mathrm{~nm}$ was captured by a CCD video camera (Photonic Science Ltd, Tunbridge Wells, UK). The time interval between successive series of 340-380 images was usually $3.3 \mathrm{~s}$, which limited the duration of the experiments to $14 \mathrm{~min}$. For longer experiments (up to $30 \mathrm{~min}$ ), the fluorescence was recorded on video tape (Sony VO-9600P). From the ratio of the fluorescence at 340 and $380 \mathrm{~nm}$, the concentration of $\mathrm{Ca}_{\mathrm{i}}{ }^{2+}$ was calculated by comparison with a calibration curve [24].

Presentation of results. All measurements of $\mathrm{Ca}_{i}^{2+}$ (calculated concentrations) are illustrated by recordings which are representative of results obtained with the indicated number of is- 
Table 1. Influence of culture conditions on $\mathrm{Ca}_{1}^{2+}$ changes occurring in mouse islets stimulated by an acute rise in glucose concentration from 3 to $15 \mathrm{mmol} / \mathrm{l}$

\begin{tabular}{|c|c|c|c|c|c|c|c|}
\hline \multirow[t]{2}{*}{ Line } & \multirow[t]{2}{*}{ Measured parameter } & \multicolumn{4}{|c|}{ Culture in $10 \mathrm{mmol} / 1$ glucose } & \multicolumn{2}{|c|}{ Culture in $5 \mathrm{mmol} / \mathrm{l}$ glucose } \\
\hline & & Day 1 & Day 2 & Day 3 & Day 4 & Day 1 & Day 4 \\
\hline (1) & $\mathrm{Ca}_{\mathrm{i}}^{2+}$ in $\mathrm{G} 3(\mathrm{nmol} / \mathrm{l})$ & $83 \pm 4$ & $70 \pm 5$ & $76 \pm 5$ & $74 \pm 3$ & $92 \pm 5$ & $66 \pm 3^{b}$ \\
\hline (2) & $\begin{array}{l}\text { Islets in which } \mathrm{G} 15 \text { induced an } \\
\text { initial decrease in } \mathrm{Ca}_{\mathrm{i}}^{2+}\end{array}$ & $37 / 38$ & $7 / 12$ & $8 / 12$ & $9 / 25$ & $14 / 14$ & $12 / 12$ \\
\hline (3) & $\begin{array}{l}\text { Initial decrease in } \mathrm{Ca}_{\mathrm{i}}{ }^{2+} \text { induced } \\
\text { by } \mathrm{G} 15(\mathrm{nmol} / \mathrm{l})\end{array}$ & $6.3 \pm 0.4$ & $6.9 \pm 1.2$ & $5.1 \pm 0.2$ & $4.2 \pm 0.4$ & $11.0 \pm 0.8^{\mathrm{d}}$ & $13.0 \pm 0.8^{\mathrm{d}}$ \\
\hline (4) & $\begin{array}{l}\text { Delay of the increase in } \mathrm{Ca}_{\mathrm{i}}^{2+} \\
\text { induced by } \mathrm{G} 15(\mathrm{~s})\end{array}$ & $92 \pm 3$ & $87 \pm 6$ & $68 \pm 4^{\mathrm{b}}$ & $55 \pm 4^{b}$ & $157 \pm 4^{\mathrm{d}}$ & $131 \pm 7^{\mathrm{b}, \mathrm{d}}$ \\
\hline (5) & $\mathrm{Ca}_{\mathrm{i}}{ }^{2+}$ at the first peak in $\mathrm{G} 15$ & $215 \pm 7$ & $217 \pm 11$ & $259 \pm 9^{a}$ & $248 \pm 9^{a}$ & $186 \pm 6^{c}$ & $198 \pm 7^{d}$ \\
\hline (6) & Delay to first peak of $\mathrm{Ca}_{\mathrm{i}}^{2+}(\mathrm{s})$ & $144 \pm 2$ & $142 \pm 6$ & $118 \pm 5^{\mathrm{b}}$ & $106 \pm 4^{\mathrm{b}}$ & $193 \pm 3^{\text {d }}$ & $169 \pm 8^{\mathrm{b}, \mathrm{d}}$ \\
\hline (7) & Rate of $\mathrm{Ca}_{\mathrm{i}}{ }^{2+}$ rise $(\mathrm{nmol} / \mathrm{s})$ & $2.6 \pm 0.1$ & $2.8 \pm 0.3$ & $3.7 \pm 0.3^{b}$ & $3.4 \pm 0.2^{b}$ & $2.5 \pm 0.2$ & $3.6 \pm 0.4^{b}$ \\
\hline (8) & $\begin{array}{l}\text { Islets showing } \mathrm{Ca}_{\mathrm{i}}{ }^{2+} \text { oscillations } \\
\text { during stimulation by } \mathrm{G} 15\end{array}$ & $38 / 38$ & $12 / 12$ & $9 / 12$ & $8 / 25$ & $14 / 14$ & $12 / 12$ \\
\hline (9) & $\begin{array}{l}\text { Average } \mathrm{Ca}_{\mathrm{i}}{ }^{2+}(\mathrm{nmol} / 1) \text { between } \\
9-12 \mathrm{~min} \text { G15 }\end{array}$ & $156 \pm 4$ & $167 \pm 8$ & $203 \pm 5^{\mathrm{b}}$ & $211 \pm 7^{b}$ & $125 \pm 5^{\mathrm{d}}$ & $115 \pm 4^{\mathrm{d}}$ \\
\hline
\end{tabular}

Values are means $\pm S E M$ for the indicated number of islets. The islets were cultured for 1-4 days in RPMI medium containing either 10 or $5 \mathrm{mmol} / \mathrm{l}$ glucose before $\mathrm{Ca}_{\mathrm{i}}{ }^{2+}$ was measured as follows. After loading for $40 \mathrm{~min}$ in a bicarbonate-buffered solution containing $10 \mathrm{mmol} / 1$ glucose and $1 \mu \mathrm{mol} / \mathrm{l} \mathrm{Fura-}$ 2-AM, the islets were perifused for $\sim 10 \mathrm{~min}$ with a medium containing $3 \mathrm{mmol} / 1$ glucose (G3). Thereafter, the concentration of glucose was raised to $15 \mathrm{mmol} / \mathrm{l}$ (G15). An initial decrease in $\mathrm{Ca}_{i}^{2+}$ was considered to be present if larger than

lets. For each culture, usually three islets were tested with the same protocol each day. A given protocol was tested in islets from at least four different cultures. The statistical significance between means was assessed either by Student's $t$-test for paired or unpaired values when only two groups were compared. For more than two groups, analysis of variance followed by Scheffés test was used. Differences were considered statistically significant at $p$ less than 0.05 .

\section{Results}

Islets cultured in $10 \mathrm{mmol} / \mathrm{l}$ glucose. After their transfer into the chamber, the islets loaded with fura-2 were perifused for about 10 min with a medium containing $3 \mathrm{mmol} / \mathrm{l}$ glucose. Under these conditions, $\mathrm{Ca}_{\mathrm{i}}{ }^{2+}$ was low and stable (Fig. 1), and not significantly affected by the duration of culture (Table 1, line 1). When the concentration of glucose was raised from 3 to $15 \mathrm{mmol} / \mathrm{l}$, a concentration that causes half-maximal stimulation of mouse beta cells [23], $\mathrm{Ca}_{\mathrm{i}}{ }^{2+}$ in islet cells changed in three phases: an initial small decrease, followed by a marked increase and eventually a more or less sustained elevation.

The initial decrease was almost always observed on day 1 of culture, but its occurrence became less frequent as the culture was prolonged. When it was present, its amplitude tended to decrease after day 2 , but this trend was not statistically significant (Table 1 , lines 2 and 3 ).
$2 \mathrm{nmol} / \mathrm{l}$; its mean size was calculated only for those islets in which it was present. The delay of the increase in $\mathrm{Ca}_{\mathrm{i}}{ }^{2+}$ was calculated at the time when $\mathrm{Ca}_{\mathrm{i}}{ }^{2+}$ was $5 \mathrm{nmol} / \mathrm{l}$ higher than in $3 \mathrm{mmol} / \mathrm{l}$ glucose. The average $\mathrm{Ca}_{\mathrm{i}}{ }^{2+}$ concentration was calculated by integrating all $\mathrm{Ca}_{\mathrm{i}}{ }_{\mathrm{i}}^{2+}$ values between 9 and $12 \mathrm{~min}$ of stimulation with $15 \mathrm{mmol} / \mathrm{l}$ glucose. ${ }^{\mathrm{a}} p<0.05,{ }^{\mathrm{b}} p<0.01$ or less vs day 1 for islets cultured at the same glucose concentration; ${ }^{\mathrm{c}} p<0.05,{ }^{\mathrm{d}} p<0.01$ or less vs islets cultured in $10 \mathrm{mmol} / 1$ glucose for the same period.

The initial increase in $\mathrm{Ca}_{\mathrm{i}}{ }^{2+}$ was similar in onset and amplitude after 1 and 2 days of culture. After 3 and 4 days, however, the increase occurred earlier and was larger than after 1 day; the rate of $\mathrm{Ca}_{i}{ }^{2+}$ rise was also higher (Table 1, lines 4-7).

After the first rise, $\mathrm{Ca}_{\mathrm{i}}{ }^{2+}$ remained elevated, but the pattern was strikingly different after 1 to 4 days of culture (Fig.1). After 1 day, rapid and fairly regular oscillations of $\mathrm{Ca}_{\mathrm{i}}{ }^{2+}$ were recorded in all islets. Their frequency was typically higher during the first minutes than under steady-state stimulation (Fig. 1 A). On days 2 and 3, much slower oscillations occurred relatively late during the stimulation. They were seen in all islets on day 2 , and in 9 of 12 islets on day 3. On day 4, most islets showed a sustained rise of $\mathrm{Ca}_{\mathrm{i}}{ }^{2+}$ (Fig. 1D); oscillations were present in only 8 of 25 islets, and their presence was often transient. The average $\mathrm{Ca}_{\mathrm{i}}^{2+}$ level (integrated between 9 and $12 \mathrm{~min}$ of stimulation with $15 \mathrm{mmol} / \mathrm{l}$ glucose) clearly increased with the duration of culture because of the disappearance of the oscillations (Table 1, line 9).

The characteristics of $\mathrm{Ca}_{i}{ }^{2+}$ oscillations occurring during steady-state stimulation were studied in islets perifused with $15 \mathrm{mmol} / 1$ glucose throughout the experiment. These oscillations are illustrated in Figure 2 and quantified in Table 2. On day 1, all islets displayed rapid and fairly regular $\mathrm{Ca}_{\mathrm{i}}{ }^{2+}$ oscillations (Fig. 2A). In some islets, however, a slower periodicity marked by deeper and longer decreases in $\mathrm{Ca}_{\mathrm{i}}{ }^{2+}$ was 
Culture G $10 \mathrm{mmol} / \mathrm{I}$
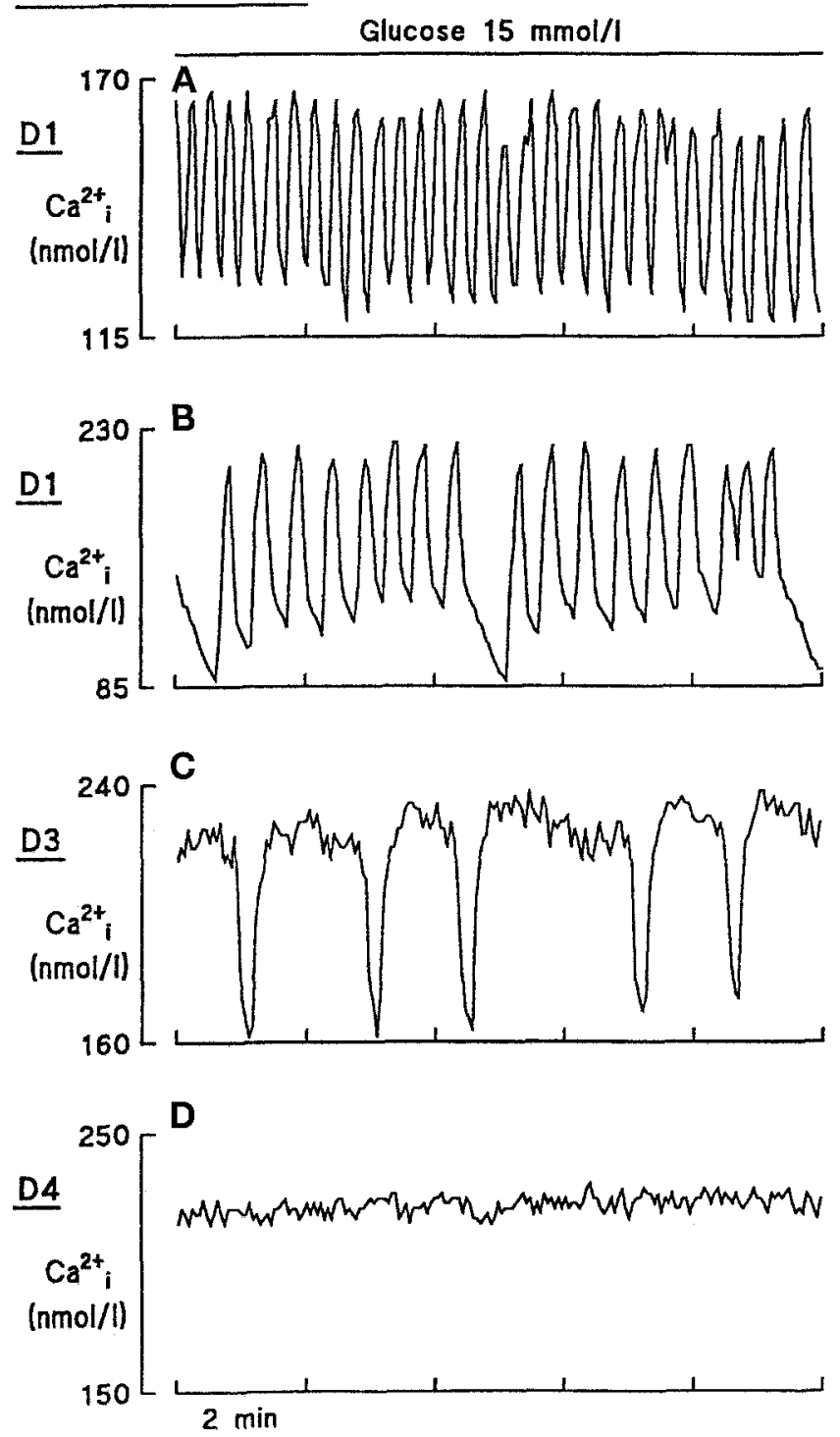

Fig. $2 \mathrm{~A}-\mathbf{D}$. Influence of culture duration on $\mathrm{Ca}_{\mathrm{i}}{ }^{2+}$ oscillations recorded in mouse islets during steady-state stimulation with $15 \mathrm{mmol} / \mathrm{l}$ glucose. The islets were cultured in RPMI $1640 \mathrm{me}$ dium containing $10 \mathrm{mmol} / 1$ glucose for 1,3 or 4 days (D1, D3 and D4). They were then loaded with fura-2, transferred to the recording chamber, and perifused with a medium containing $15 \mathrm{mmol} / \mathrm{l}$ glucose for about $12 \mathrm{~min}$ before $\mathrm{Ca}_{\mathrm{i}}{ }^{2+}$ measurements started. Note that the scale for $\mathrm{Ca}_{i}{ }^{2+}$ is not the same in the different panels. These recordings are representative of results obtained in 12 islets (D1 and D3) or 15 islets (D4)

also observed (Fig. 2B). On day 2, $\mathrm{Ca}_{\mathrm{i}}^{2+}$ oscillations were consistently present, but their frequency was much lower than on day 1 (Table 2). On day 3 , the proportion of islets with $\mathrm{Ca}_{\mathrm{i}}{ }^{2+}$ oscillations decreased, but the frequency of these oscillations was similar to that of islets on day 2. There were no $\mathrm{Ca}_{\mathrm{i}}{ }^{2+}$ oscillations on day 4 . Table 2 (line 3 ) also shows that the average $\mathrm{Ca}_{i}{ }^{2+}$ level (integrated over the 14 min of recording regardless of the presence of oscillations) increased with the duration of culture.
We have previously reported that $\mathrm{Ca}_{\mathrm{i}}{ }^{2+}$ oscillations are synchronous in all subregions of islets stimulated by $15 \mathrm{mmol} / \mathrm{l}$ glucose after 1 day of culture in $10 \mathrm{mmol} / \mathrm{l}$ glucose [24]. In the 7 of 12 islets which displayed oscillations after 3 days of culture (Table 2 , line 1), the oscillations were also found to be synchronous in all subregions. In the other five islets no oscillations were detected in any subregion. Similarly, in six islets which did not show $\mathrm{Ca}_{\mathrm{i}}{ }^{2+}$ oscillations after 4 days of culture, the $\mathrm{Ca}_{i}{ }^{2+}$ signal was also found to be stable when analysed in subregions.

Experiments were also performed with a $\mathrm{Ca}^{2+}$-free medium. In the presence of $3 \mathrm{mmol} / \mathrm{l}$ glucose, the average $\mathrm{Ca}_{\mathrm{i}}{ }^{2+}$ concentration was $38 \pm 3 \mathrm{nmol} / \mathrm{l}$ and $43 \pm 2 \mathrm{nmol} / \mathrm{l}$ after 1 and 4 days of culture, respectively. Stimulation by $15 \mathrm{mmol} / \mathrm{l}$ glucose similarly and significantly ( $p<0.001$ by paired $t$-test; $n=8$ ) lowered $\mathrm{Ca}_{\mathrm{i}}{ }^{2+}$ in both series of islets, by $4.2 \pm 0.2 \mathrm{nmol} / 1$ and by $4.6 \pm 0.6 \mathrm{nmol} / 1$, respectively.

Islets cultured in 5 mmol/l glucose. In the presence of $3 \mathrm{mmol} / \mathrm{l}$ glucose, $\mathrm{Ca}_{\mathrm{i}}{ }^{2+}$ was lower in islets cultured for 4 days than in islets cultured for 1 day only, but there was no significant difference with islets cultured for the same period of time in a medium containing $10 \mathrm{mmol} / \mathrm{l}$ glucose (Table 1 , line 1 ).

When the glucose concentration was raised from 3 to $15 \mathrm{mmol} / \mathrm{l}, \mathrm{Ca}_{\mathrm{i}}{ }^{2+}$ again changed in three phases (Fig.3). The initial fall was much larger than after culture in $10 \mathrm{mmol} / \mathrm{l}$ glucose, and was seen in all islets, even after 4 days of culture (Table 1, lines 2 and 3 ). The subsequent increase in $\mathrm{Ca}_{\mathrm{i}}{ }^{2+}$ occurred slightly sooner after 4 days than after 1 day of culture, but reached a similar peak value. Compared with islets cultured in $10 \mathrm{mmol} / 1$ glucose, the $\mathrm{Ca}_{\mathrm{i}}{ }^{2+}$ rise was delayed and its amplitude was smaller (Table 1, lines 4-7).

Subsequently, $\mathrm{Ca}_{\mathrm{i}}{ }^{2+}$ started to oscillate following different patterns (Fig.3). On day 1, relatively rapid oscillations of small amplitude appeared for a few min before being replaced by much larger and slower oscillations. This pattern was observed in most of the islets, whether the loading with fura- 2 was performed in the presence of 10 or $5 \mathrm{mmol} / 1$ glucose (compare Fig. $3 \mathrm{~A}$ and B). In a minority of islets $\mathrm{Ca}^{2+}$ remained elevated without oscillations between the initial large peak and the slow oscillations. After 4 days of culture, only slow $\mathrm{Ca}_{\mathrm{i}}{ }^{2+}$ oscillations were seen (Fig. 3C).

The $\mathrm{Ca}_{\mathrm{i}}{ }^{2+}$ oscillations that occurred during steadystate stimulation with $15 \mathrm{mmol} / \mathrm{l}$ glucose are shown in greater detail in Figure 4. It is evident that they were markedly different after 1 and 4 days of culture. After 1 day, they were complex, often composed of slow, ample fluctuations of $\mathrm{Ca}_{i}{ }^{2+}$ and of fast, smaller changes (Table 2). These faster oscillations were either present all the time or only on top of the slow oscillations (Fig.4A and B). On the other hand, the oscillations were always slow and simple after 
Table 2. Influence of culture conditions on the characteristics of $\mathrm{Ca}_{\mathrm{i}}{ }^{2+}$ in mouse islets during continuous perifusion with a medium containing $15 \mathrm{mmol} / \mathrm{l}$ glucose

\begin{tabular}{|c|c|c|c|c|c|c|c|}
\hline \multirow{2}{*}{ Line } & \multirow{2}{*}{ Measured parameter } & \multicolumn{4}{|c|}{ Culture in $10 \mathrm{mmol} / 1$ glucose } & \multicolumn{2}{|c|}{ Culture in $5 \mathrm{mmol} / 1$ glucose } \\
\hline & & Day 1 & Day 2 & Day 3 & Day 4 & Day 1 & Day 4 \\
\hline $\begin{array}{l}\text { (1) } \\
\text { (2) }\end{array}$ & $\begin{array}{l}\text { Proportion of islets with } \mathrm{Ca}_{\mathrm{i}}^{2+} \\
\text { oscillations } \\
\text { Frequency of the } \mathrm{Ca}_{\mathrm{i}}^{2+} \\
\text { oscillations (per min) }\end{array}$ & $12 / 12$ & $12 / 12$ & $7 / 12$ & $0 / 15$ & $14 / 14$ & $18 / 18$ \\
\hline & $\begin{array}{l}\text { Fast } \\
\text { Slow }\end{array}$ & $2.6 \pm 0.4$ & $1.0 \pm 0.2^{\mathrm{b}}$ & $0.9 \pm 0.2^{b}$ & 0 & $\begin{array}{l}2.5 \pm 0.2(11) \\
0.21 \pm 0.02(12)\end{array}$ & $\begin{array}{l}0 \\
0.38 \pm 0.05^{\mathrm{b}}(18)\end{array}$ \\
\hline (3) & Average $\mathrm{Ca}_{\mathrm{i}}{ }^{2+}(\mathrm{nmol} / 1)$ & $145 \pm 9$ & $162 \pm 6$ & $192 \pm 11^{\mathrm{a}}$ & $217 \pm 12^{b}$ & $125 \pm 6^{\mathrm{c}}$ & $116 \pm 7^{\mathrm{d}}$ \\
\hline
\end{tabular}

Values are means \pm SEM for the indicated number of islets. After culture and loading with fura-2, the islets were immediately and continuously perifused with a medium containing $15 \mathrm{mmol} / \mathrm{l}$ glucose. The measurements of $\mathrm{Ca}_{\mathrm{i}}{ }^{2+}$ started about 12 min after the start of this perifusion. On day 3 of the culture in $10 \mathrm{mmol} / 1$ glucose, the frequency of $\mathrm{Ca}_{\mathrm{i}}{ }^{2+}$ oscillations was calculated only for those 7 islets displaying oscillations.

4 days (Fig. $4 \mathrm{C}$ and $\mathrm{D}$ ). The average $\mathrm{Ca}_{\mathrm{i}}^{2+}$ level during glucose stimulation was not different between days 1 and 4 , but clearly lower than in islets cultured for the same time in $10 \mathrm{mmol} / \mathrm{l}$ glucose (Tables 1 and 2 ).

We also investigated whether the mixed oscillations of $\mathrm{Ca}_{\mathrm{i}}^{2+}$ recorded after culture of the islets in $5 \mathrm{mmol} / 1$ glucose were synchronous in all subregions of the organ. After 1 day of culture, a good synchrony of both slow and fast $\mathrm{Ca}_{\mathrm{i}}{ }^{2+}$ oscillations was observed in 14 of 14 islets stimulated by $15 \mathrm{mmol} / \mathrm{l} \mathrm{glu}-$ cose throughout (Fig. 5A). On the other hand, slight desynchronization of $\mathrm{Ca}_{\mathrm{i}}{ }^{2+}$ oscillations was observed in 7 of 18 islets cultured for 4 days in $5 \mathrm{mmol} / \mathrm{l} \mathrm{glu-}$ cose. In the islet shown in Figure $5 \mathrm{~B}$, five oscillations occurred in region 5 and only four in quarters 2 and 3 during the period of observation. Although the desynchronization was limited in this example, it is the most striking one that we have observed.

\section{Discussion}

The present study shows that the characteristics of glucose-induced $\mathrm{Ca}_{\mathrm{i}}{ }^{2+}$ changes in normal mouse islets are markedly modified by the duration of the culture and by the concentration of glucose during the culture period. It has previously been established that, although islets from normal mice contain about $20 \%$ of non-beta cells, the characteristics of the $\mathrm{Ca}_{\mathrm{i}}{ }^{2+} \mathrm{sig}$ nals recorded from the microorgan essentially reflect events occurring in beta cells $[21,22,24,26]$.

Acute stimulation of the islets by a rise of the glucose concentration from 3 to $15 \mathrm{mmol} / 1$ produced an initial lowering of $\mathrm{Ca}_{\mathrm{i}}^{2+}$ which has been observed in other studies [8, 13, 19, 24, 27]. This decrease is thought to reflect $\mathrm{Ca}^{2+}$ sequestration in cellular organelles, but its functional significance is unclear. It was most pronounced after culture in $5 \mathrm{mmol} / \mathrm{l} \mathrm{glu}-$ cose, and became smaller and inconsistent when the
On day 1 of the culture in $5 \mathrm{mmol} / \mathrm{l}$ glucose, 9 islets showed mixed (fast and slow) oscillations, 2 islets only fast oscillations, and 3 islets only slow oscillations. ${ }^{\mathrm{a}} p<0.05,{ }^{\mathrm{b}} p<0.01$ or less vs day 1 for islets cultured at the same glucose concentration; ${ }^{\mathrm{c}} p<0.05,{ }^{\mathrm{d}} p<0.01$ or less vs islets cultured in $10 \mathrm{mmol} / 1$ glucose for the same period

culture in $10 \mathrm{mmol} / \mathrm{l}$ glucose was extended beyond 2 days. We attribute this apparent disappearance to a masking by the faster subsequent rise in $\mathrm{Ca}_{\mathrm{i}}{ }^{2+}$. Thus, when experiments were performed in the absence of extracellular $\mathrm{Ca}^{2+}$, glucose similarly lowered $\mathrm{Ca}_{i}{ }^{2+}$ after 1 and 4 days of culture. These observations are in agreement with the report that the initial lowering of $\mathrm{Ca}_{\mathrm{i}}{ }^{2+}$ was more easily detected when dispersed islet cells were stimulated by glucose after preincubation in 3 rather than $20 \mathrm{mmol} / \mathrm{l}$ glucose [13].

The initial small decrease was followed by a large first phase increase of $\mathrm{Ca}_{\mathrm{i}}{ }^{2+}$, which was little affected by culture conditions and duration. The major impact of culture was on $\mathrm{Ca}_{i}{ }^{2+}$ oscillations occurring during steady-state stimulation with glucose. Depending on the conditions, these oscillations progressively disappeared or changed in shape and frequency. Elucidation of the causes of the complex changes in $\mathrm{Ca}_{\mathrm{i}}{ }^{2+} \mathrm{re}-$ sponses induced by culture is not easy and would first require identification of the regulatory mechanisms that control $\mathrm{Ca}_{i}{ }^{2+}$ oscillations. However, some conclusions can already be drawn from our observations.

In both freshly isolated islets [22] and in islets cultured for only 1 day in $10 \mathrm{mmol} / 1$ glucose [24], fast $\mathrm{Ca}_{\mathrm{i}}{ }^{2+}$ oscillations are synchronous in all subregions of the islets and display the same characteristics as the oscillations of beta-cell membrane potential. Glucose-induced electrical activity is altered in single mouse beta cells $[28,29]$, which might have to be electrically coupled in order to display regular slow waves [30]. A regular pattern of fast $\mathrm{Ca}_{\mathrm{i}}{ }^{2+}$ oscillations has never been described in single mouse beta cells cultured for 1-2 days in RPMI medium with $11 \mathrm{mmol} / \mathrm{l}$ glucose and then stimulated by various concentrations of the sugar. They usually display $\mathrm{Ca}_{\mathrm{i}}{ }^{2+}$ oscillations with a slow frequency of $0.05-0.5 / \mathrm{min}$ [18], similar to the slow oscillations that we observe in islets cultured for 4 days in $5 \mathrm{mmol} / 1$ glucose. We therefore investigated whether the changes in the $\mathrm{Ca}_{\mathrm{i}}{ }^{2+}$ pat- 
Culture G $5 \mathrm{mmol} / 1$
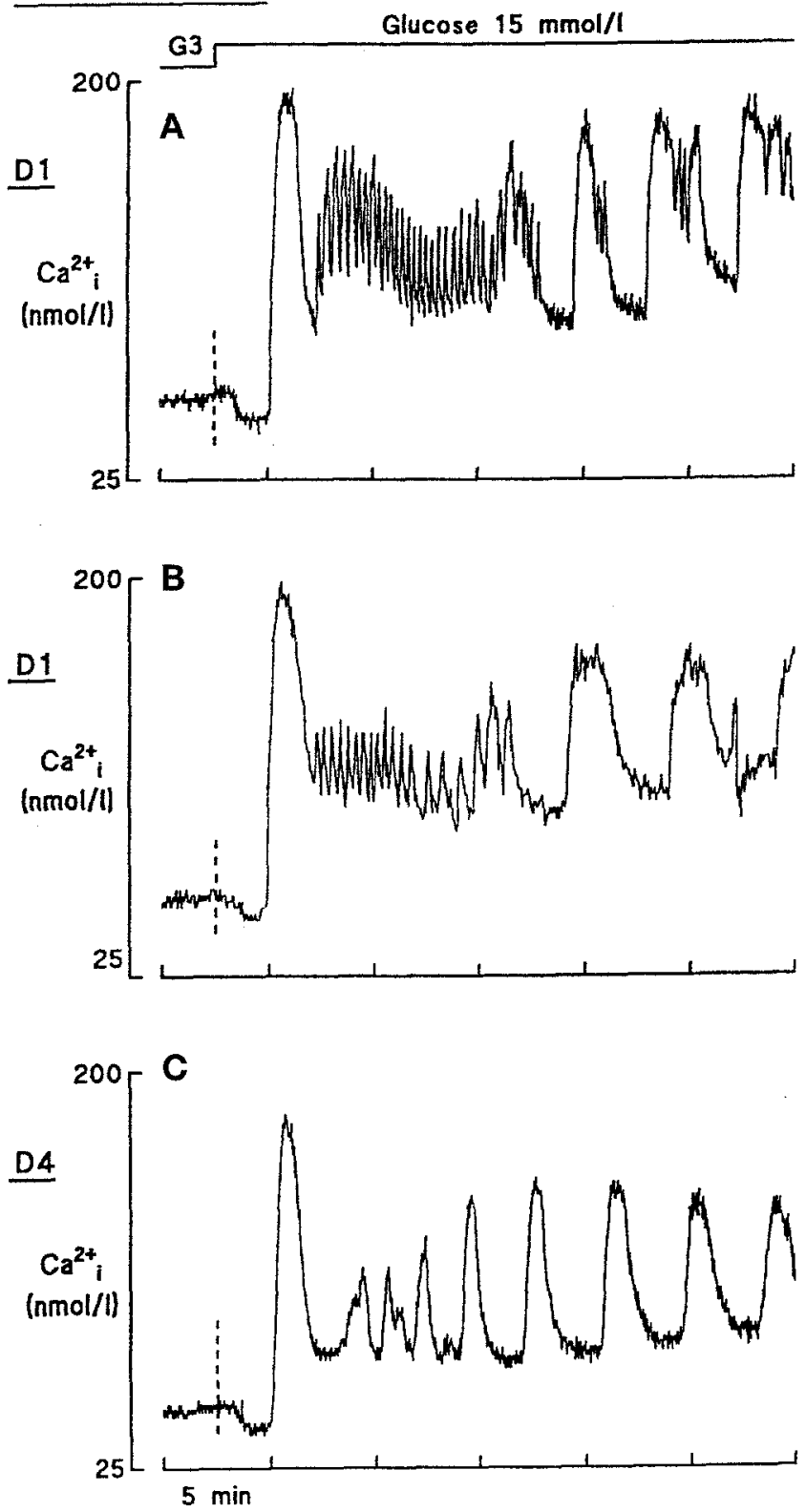

Fig. 3A-C. Influence of culture duration on the changes in $\mathrm{Ca}_{\mathrm{i}}^{2+}$ occurring in mouse islets stimulated by an increase in glucose (G) concentration from 3 to $15 \mathrm{mmol} / \mathrm{l}$. The islets were cultured in RPMI 1640 medium containing $5 \mathrm{mmol} / 1$ glucose for 1 or 4 days (D1 and D4). They were then loaded with fura2 in the presence of $10 \mathrm{mmol} / \mathrm{l}$ glucose $(A$ and $C$ ) or $5 \mathrm{mmol} / 1$ glucose (B). After their transfer to the recording chamber, the islets were perifused with a medium containing $3 \mathrm{mmol} / \mathrm{l} \mathrm{glu}-$ cose for about 10 min before $\mathrm{Ca}_{\mathrm{i}}^{2+}$ measurements started. These recordings are representative of results obtained in 11 , 6 and 9 islets, respectively

tern observed during culture could be due to desynchronization of the oscillations occurring in different regions of the islets. This, however, could not explain the loss of $\mathrm{Ca}_{\mathrm{i}}{ }^{2+}$ oscillations occurring during culture in $10 \mathrm{mmol} / 1$ glucose or the appearance of mixed oscillations (fast $\mathrm{Ca}_{\mathrm{i}}{ }^{2+}$ transients on top of slower ones) after 1 day of culture in $5 \mathrm{mmol} / 1$ glucose. Even after
Culture $G 5 \mathrm{mmol} / 1$
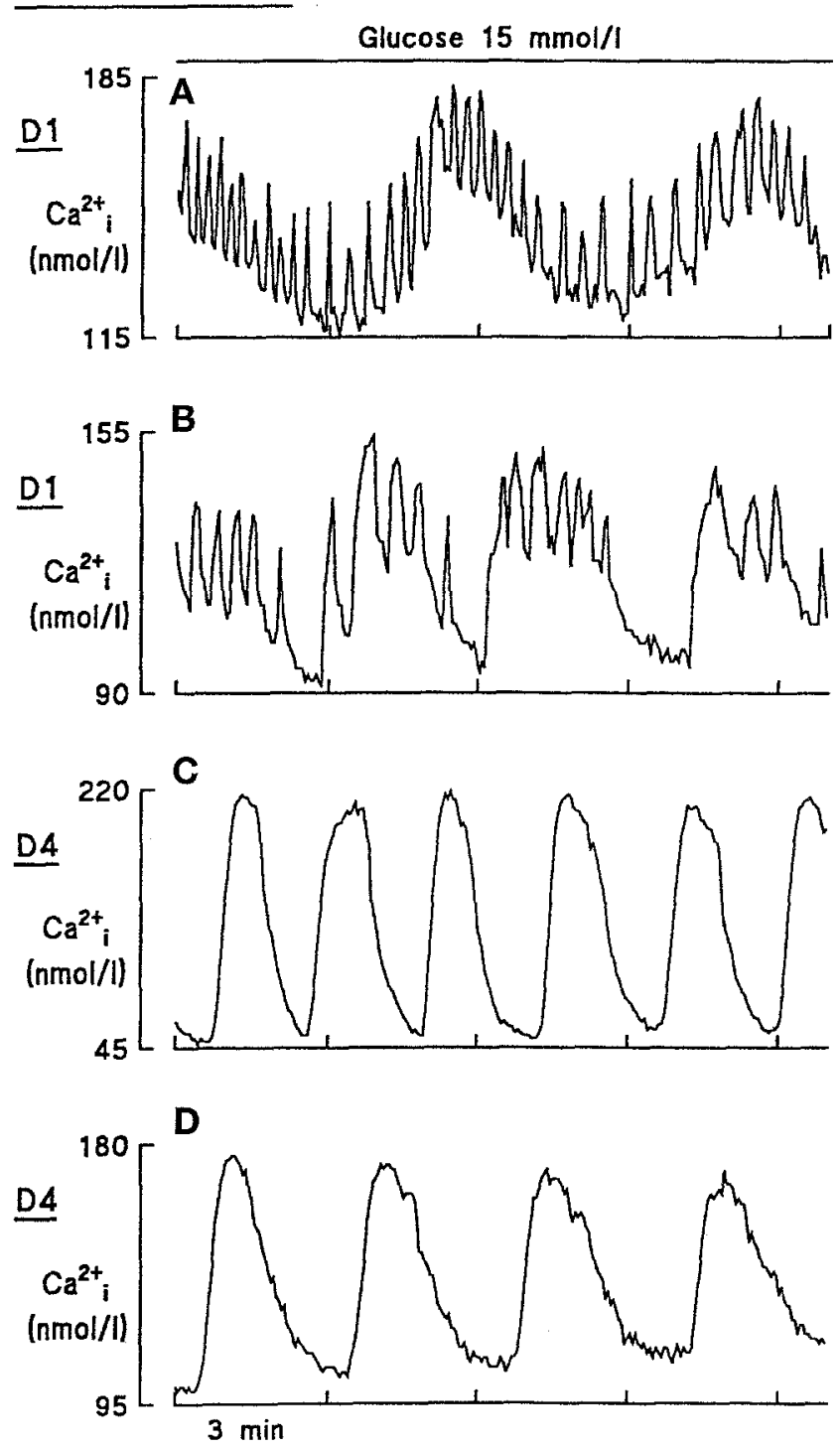

Fig. 4 A-D. Influence of culture duration on $\mathrm{Ca}_{\mathrm{i}}{ }^{2+}$ oscillations recorded in mouse islets during steady-state stimulation with $15 \mathrm{mmol} / 1$ glucose. The islets were cultured in RPMI $1640 \mathrm{me}-$ dium containing $5 \mathrm{mmol} / \mathrm{l}$ glucose for 1 or 4 days (D1 and D4). They were then loaded with fura-2, transferred to the recording chamber, and perifused with a medium containing $15 \mathrm{mmol} / \mathrm{l}$ glucose for about $12 \mathrm{~min}$ before $\mathrm{Ca}_{\mathrm{i}}{ }^{2+}$ measurements started. Note that the scale for $\mathrm{Ca}_{\mathrm{i}}{ }^{2+}$ is not the same in the different panels. These recordings are representative of results obtained in 14 and 18 islets, respectively

4 days of culture in $5 \mathrm{mmol} / \mathrm{l}$ glucose, most of the islets maintained good synchrony between all regions studied. Only in a few islets did we find partial desynchronization. We do not believe, therefore, that a loss of beta cell synchrony is the primary cause of the changes of $\mathrm{Ca}_{\mathrm{i}}{ }^{2+}$ pattern occurring under our culture conditions. That other factors are involved is indirectly supported by the observation that mixed oscillations occurred in a higher proportion of single beta cells when these were studied just after isolation than after 1-2 days of culture [18]. 


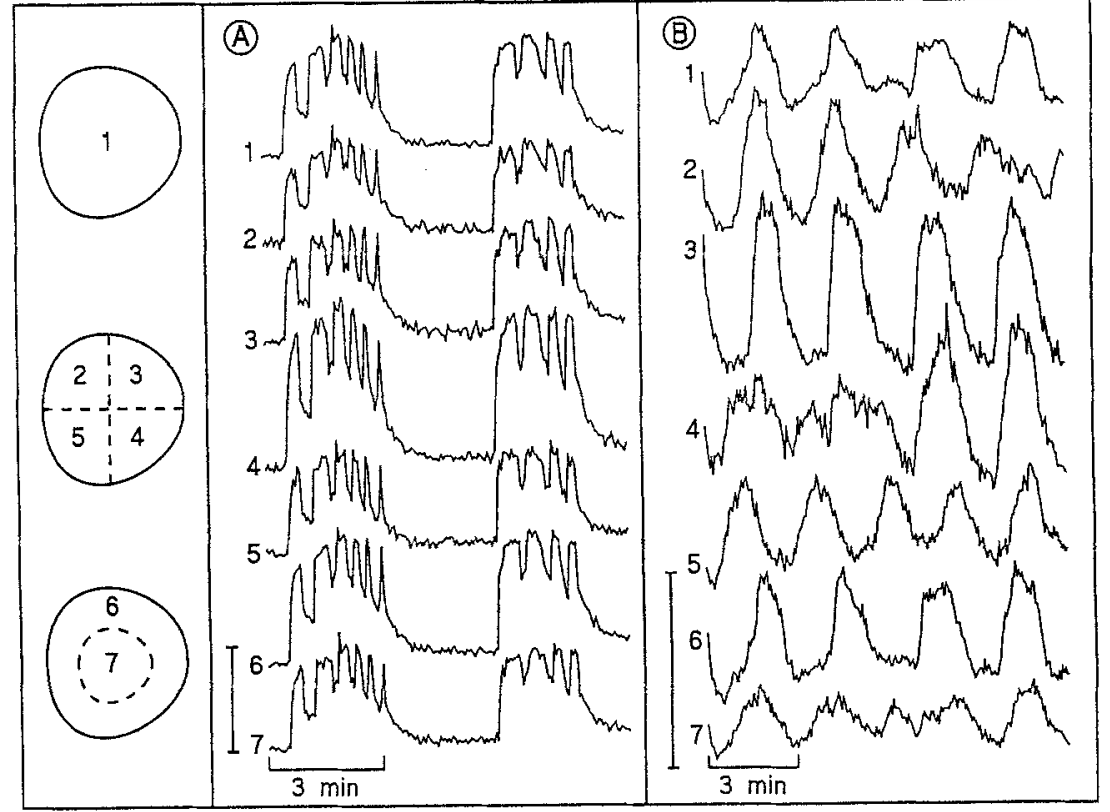

Fig. 5 A, B. Influence of culture duration on the synchrony of $\mathrm{Ca}_{i}^{2+}$ oscillations in various regions of islets stimulated by $15 \mathrm{mmol} / \mathrm{l} \mathrm{glu}$ cose. The mean $\mathrm{Ca}_{\mathrm{i}}{ }^{2+}$ was determined in the whole islet (1) or in the subregions (2-7). The islets were cultured in RPMI 1640 medium containing $5 \mathrm{mmol} / 1$ glucose for 1 day (A) or for 4 days (B). The vertical calibration bars correspond to $100 \mathrm{nmol} / \mathrm{l} \mathrm{Ca} \mathrm{i}^{2+}$
The changes in glucose metabolism that take place in islet cells during culture at various glucose concentrations $[31,32]$ are likely to play some role. The progressively more rapid and sustained elevation of $\mathrm{Ca}_{i}{ }^{2+}$ after longer culture in $10 \mathrm{mmol} / \mathrm{l}$ glucose might be a consequence of the acceleration of glucose metabolism under these conditions. This interpretation is compatible with our unpublished observations that 1) slow $\mathrm{Ca}_{i}{ }^{2+}$ oscillations reappeared in islets cultured for 4 days when the concentration of glucose was reduced from 15 to $10 \mathrm{mmol} / 1$ in the perifusion medium and 2) culture barely affected the $\mathrm{Ca}_{\mathrm{i}}{ }^{2+}$ changes induced by arginine, an amino acid which does not affect beta cell function through changes in metabolism [33]. The observations that the $\mathrm{Ca}_{\mathrm{i}}{ }^{2+}$ rises brought about by arginine or by glucose (during both first and second phase) were not attenuated by 4 days of culture also speak against the possibility that culture markedly affected voltage-dependent $\mathrm{Ca}^{2+}$ channels.

The present study raises the question of what is the normal pattern of glucose-induced $\mathrm{Ca}_{\mathrm{i}}{ }^{2+}$ changes in beta cells. For the mouse beta cell, the pattern that we observed after no more than 1 day of culture in $10 \mathrm{mmol} / \mathrm{l}$ glucose is similar to that observed by others in non-cultured islets $[21,22]$. It also closely resembles the changes in beta cell membrane potential (more specifically of the $\mathrm{Ca}^{2+}$-dependent electrical activity) recorded in islets still within the pancreas and studied rapidly after the death of the animal [4, 24]. In a minority of freshly isolated islets, $11 \mathrm{mmol} / \mathrm{l}$ glucose produced mixed $\mathrm{Ca}_{i}{ }^{2+}$ oscillations or slow $\mathrm{Ca}_{\mathrm{i}}{ }^{2+}$ oscillations [21] similar to those observed here after 1 and 4 days of culture in $5 \mathrm{mmol} / \mathrm{l}$ glucose, respectively. We did not record the purely slow pattern in islets cultured for 1 day in $10 \mathrm{mmol} / 1$ glucose and subsequently challenged by $15 \mathrm{mmol} / \mathrm{l}$ glucose. However, a mixed pattern was occasionally observed, and may be more frequent during stimulation by 10 than $15 \mathrm{mmol} / \mathrm{l}$ [34 and our unpublished data]. It is possible that these mixed $\mathrm{Ca}_{\mathrm{i}}{ }^{2+}$ oscillations correspond to the periodic electrical activity that is sometimes recorded in fresh islets [35]. In intact rat islets cultured for 2-4 days in the presence of $10 \mathrm{mmol} / 1$ glucose, acute challenge with $10 \mathrm{mmol} / \mathrm{l}$ glucose induced slow $\mathrm{Ca}_{\mathrm{i}}{ }^{2+}$ oscillations with a frequency of about 0.25 per min [25]. No fast oscillations have been described in that study with rat islets, but they could not have been detected by sampling images every $20-30 \mathrm{~s}$ only [25].

The most important message of our work is that great caution should be exercised when drawing conclusions from $\mathrm{Ca}_{\mathrm{i}}{ }^{2+}$ measurements obtained in beta cells or in islets cultured for several days. In addition to the actual conditions of measurements both culture duration and conditions may affect the responses. This complicates the analysis of the abnormalities of stimulus-secretion coupling in beta cells from animal models of diabetes, and adds to the difficulties of studying human beta cells.

Acknowledgements. We thank Dr. R. M. Shepherd for her help with some experiments, Mr. M. Nicaise for skilled assistance and M.Nenquin for editorial help. P. Gilon is Chargé de Recherches and J. C. Jonas is Aspirant of the Fonds National de la Recherche Scientifique, Brussels. This work was supported by Grants 3.4607 .90 and 9.4511 .89 from the Fonds de la Recherche Scientifique Médicale, Brussels, and by Grant SPPS-AC 89/95-135 from the Ministry of Scientific Policy, Brussels. 


\section{References}

1. Grodsky GM, Bennett LL (1966) Cation requirements for insulin secretion in the isolated perfused pancreas. Diabetes 15: 910-913

2. Milner RDG, Hales CN (1967) The role of calcium and magnesium in insulin secretion from rabbit pancreas studied in vitro. Diabetologia 3: 47-49

3. Wollheim CB, Sharp GWG (1981) The regulation of insulin release by calcium. Physiol Rev 61: 914-973

4. Henquin JC, Meissner HP (1984) Significance of ionic fluxes and changes in membrane potential for stimulus-secretion coupling in pancreatic B-cells. Experientia 40: 10431052

5. Prentki M, Matschinsky FM (1987) $\mathrm{Ca}^{2+}$, cAMP, and phospholipid-derived messengers in coupling mechanisms of insulin secretion. Physiol Rev 67: 1185-1248

6. Ashcroft FM, Rorsman P (1989) Electrophysiology of the pancreatic $\beta$-cell. Prog Biophys Mol Biol 54: 87-143

7. Cook DL, Satin LS, Hopkins WF (1991) Pancreatic $\beta$ cells are bursting, but how. Trends Neurosci. 14: 411-414

8. Rorsman P, Abrahamsson H, Gylfe E, Hellman B (1984) Dual effects of glucose on the cytosolic $\mathrm{Ca}^{2+}$ activity of mouse pancreatic $\beta$-cells. FEBS Lett 170: 196-200

9. Deleers M, Mahy M, Malaisse WJ (1985) Glucose increases cytosolic $\mathrm{Ca}^{2+}$ activity in pancreatic islet cells. Biochem Int 10: 97-103

10. Wollheim CB, Pozzan T (1984) Correlation between cytosolic free $\mathrm{Ca}^{2+}$ and insulin release in an insulin-secreting cell line. J Biol Chem 25: 2262-2267

11. Herchuelz A, Juvent M, Van Ganse E, Gobbe P (1986) Differential effect of nutrient and non-nutrient secretagogues on cytosolic free $\mathrm{Ca}^{2+}$ in pancreatic islet cells. In: Atwater I, Rojas E, Soria B (eds) Biophysics of the pancreatic $\beta$ cell. New York, Plenum Press, pp 317-318

12. Sussman KE, Leitner JW, Draznin B (1987) Cytosolic freecalcium concentrations in normal pancreatic islet cells. Effect of secretagogues and somatostatin. Diabetes 36: 571577

13. Gylfe E (1988) Glucose-induced early changes in cytoplasmic calcium of pancreatic $\beta$-cells studied with time-shating dual-wavelength fluorometry. J Biol Chem 263: 5044 5048

14. Grapengiesser E, Gylfe E, Hellman B (1988) Glucose-induced oscillations of cytoplasmic $\mathrm{Ca}^{2+}$ in the pancreatic $\beta$ cell. Biochem Biophys Res Commun 151: 1299-1304

15. Wang J-L, McDaniel ML (1990) Secretagogue-induced oscillations of cytoplasmic $\mathrm{Ca}^{2+}$ in single $\beta$ and $\alpha$-cells obtained from pancreatic islets by fluorescence-activated cell sorting. Biochem Biophys Res Commun 166: 813-818

16. Pralong W-F, Bartley C, Wollheim CB (1990) Single islet $\beta$ cell stimulation by nutrients: relationship between pyridine nucleotides, cytosolic $\mathrm{Ca}^{2+}$ and secretion. EMBO J 9: 53-60

17. Herchuelz A, Pochet R, Pastiels Ch, Van Praet A (1991) Heterogeneous changes in $\left[\mathrm{Ca}^{2+}\right]_{\mathrm{i}}$ induced by glucose, tolbutamide and $\mathrm{K}^{+}$in single rat pancreatic $\mathrm{B}$ cells. Cell Calcium 12: 577-586

18. Hellman B, Gylfe E, Grapengiesser E, Lund P-E, Berts A (1992) Cytoplasmic $\mathrm{Ca}^{2+}$ oscillations in pancreatic $\beta$-cells. Biochim Biophys Acta 1113: 295-305

19. Theler JM, Mollard P, Guérineau N, Vacher P, Pralong WF, Schlegel W, Wollheim CB (1992) Video imaging of cytosolic $\mathrm{Ca}^{2+}$ in pancreatic $\beta$-cells stimulated by glucose, carbachol, and ATP. J Biol Chem 267: 18110-18117
20. Wang JL, Corbett JA, Marshall CA, McDaniel ML (1993) Glucose-induced insulin secretion from purified $\beta$-cells. A role for modulation of $\mathrm{Ca}^{2+}$ influx by cAMP- and protein kinase $\mathrm{C}$-dependent signal transduction pathways. J Biol Chem 268: 7785-7791

21. Valdeolmillos M, Santos RM, Contreras D, Soria B, Rosario LM (1989) Glucose-induced oscillations of intracellular $\mathrm{Ca}^{2+}$ concentration resembling bursting electrical activity in single mouse islets of Langerhans. FEBS Lett 25: 19 23

22. Santos RM, Rosario LM, Nadal A, Garcia-Sancho J, Soria B, Valdeolmillos M (1991) Widespread synchronous $\left[\mathrm{Ca}^{2+}\right]_{\mathrm{i}}$ oscillations due to bursting electrical activity in single pancreatic islets. Pflügers Arch 418: 417-422

23. Zhang A, Gao ZY, Gilon P, Nenquin M, Drews G, Henquin JC (1991) Vanadate stimulation of insulin release in normal mouse islets. J Biol Chem 266: 21649-21656

24. Gilon P, Henquin JC (1992) Influence of membrane potential changes on cytoplasmic $\mathrm{Ca}^{2+}$ concentration in an electrically excitable cell, the insulin-secreting pancreatic Bcell. J Biol Chem 267: 20713-20720

25. Longo EA, Tornheim K, Deeney JT, Varnum BA, Tíllotson D, Prentki M, Corkey BE (1991) Oscillations in cytosolic free $\mathrm{Ca}^{2+}$, oxygen consumption, and insulin secretion in glucose-stimulated rat pancreatic islets. J Biol Chem 266: $9314-9319$

26. Gilon P, Shepherd RM, Henquin JC (1993) Oscillations of secretion driven by oscillations of cytoplasmic $\mathrm{Ca}^{2+}$ as evidenced in single pancreatic islets. J Biol Chem 268: 2226522268

27. Yada T, Kakei M, Tanaka H (1992) Single pancreatic $\beta$ cells from normal rats exhibit an initial decrease and subsequent increase in cytosolic free $\mathrm{Ca}^{2+}$ in response to glucose. Cell Calcium 13: 69-76

28. Smith PA, Ashcroft FM, Rorsman P (1990) Simultaneous recordings of glucose dependent electrical activity and ATP-regulated $\mathrm{K}^{+}$-currents in isolated mouse pancreatic $\beta$-cells. FEBS Lett 261: 187-190

29. Dunne MJ, Petersen OH (1991) Potassium selective ion channels in insulin-secreting cells: physiology, pharmacology and their role in stimulus-secretion coupling. Biochim Biophys Acta 1071: 67-82

30. Smolen P, Rinzel J, Sherman A (1993) Why pancreatic islets burst but single $\beta$ cells do not. The heterogeneity hypothesis. Biophys J 64: 1668-1680

31. Andersson A (1974) Long-term effects of glucose on insulin release and glucose oxidation by mouse pancreatic islets maintained in tissue culture. Biochem J 140: 377-382

32. Svensson C, Hellerström C (1991) Long-term effects of a high glucose concentration in vitro on the oxidative metabolism and insulin production of isolated rat pancreatic islets. Metabolism 40: 513-518

33. Henquin JC (1992) The biophysical events involved in the stimulation of insulin release by arginine. In: De Deyn PP, Marescau B, Stalon V, Qureshi IA (eds) Guanidino compounds in biology and medicine. John Libbey \& Company Ltd, pp 109-116

34. Bergsten P, Grapengiesser E, Gylfe E, Tengholm A, Hellman B (1994) Synchronous oscillations of cytoplasmic $\mathrm{Ca}^{2+}$ and insulin release in glucose-stimulated pancreatic islets. J Biol Chem 269: 8749-8753

35. Henquin JC, Meissner HP, Schmeer W (1982) Cyclic variations of glucose-induced electrical activity in pancreatic Bcells. Pflügers Arch 393: 322-327 